\title{
Bacterial Translocation Relationship with Enteral L-Glutamine and L-Alanine in Experimental Rat Burn Model
}

\author{
Deneysel Sıçan Yanık Modelinde, Enteral L-Glutamin ve L-Alanin ile \\ Bakteriyel Translokasyon İlişkisi
}

\author{
(D) Semih Günayl, (D Perçin Karakol2, (D) Mehmet Bozkurt², (D) Mustafa Durgun³ \\ 1Private Clinic Doctor, Plastic, Reconstructive and Aesthetic Surgery, İstanbul, Turkey \\ 2University of Health Sciences Turkey, Bağcllar Training and Research Hospital, Clinic of Plastic, Reconstructive and Aesthetic Surgery, İstanbul, \\ Turkey \\ 3Private Clinic Doctor, Plastic, Reconstructive and Aesthetic Surgery, İzmir, Turkey
}

\section{Abstract}

Objective: The aim of this experimental study is to research the effects of L-alanine and L-glutamine, which are being widely used on intensive care patients, on the liver, structural changes in the small intestine, wound healing, and bacterial translocation.

Method: Twenty male Sprague Dawley rats which weighe 190-230 gr were used in this study. Rats were separated into two randomized groups. In accordance with experimental rat burn model, skin burn was created in every rat and both groups were fed equally for 21 days. The experimental group was administered L-glutamine $+\mathrm{L}$-alanine containing product (Dipeptiven ${ }^{\circledR}$, Fresenius Kabi BadHamborg, Germany) for $5 \mathrm{~mL} / \mathrm{kg} /$ day orally. At the end of the $21^{\text {st }}$ day, all rats were sacrificed. Biopsy materials were obtained from the liver, small intestine, and burn wound, and blood culture was taken under sterile conditions. In pathologic examination, structural changes in tissues and wound healing were evaluated. In microbiologic examination, the effects of L-glutamine and L-alanine on bacterial translocation were evaluated by comparing small intestine and blood cultures.

Results: No structural difference was seen among small intestine biopsies between two groups. No liver damage was seen in the experimental group while live biopsies showed grade 1 damage in the control group. Epithelization and granulation were detected as better in the pathologic examination of skin biopsies obtained from burn wound in the experimental group. Microbiologic examination showed bacterial replication in a total of 4 rats from the control group, two rats showed

\section{Öz}

Amaç: Bu deneysel çalışmanın amacı, yoğun bakım hastalarında sıklıkla kullanılan L-alanin + L-glutaminin, karaciğer, ince bağırsaktaki yapısal değişikliklere, yara iyileşmesine ve bakteriyel translokasyona etkilerinin araştırılmasıdır.

Yöntem: Bu çalışmada 190-230 gr olan 20 adet erkek Sprague Dawley rat kullanıldı. Deney, 2 grup üzerinde tasarlandı. Tüm ratlarda, deneysel rat yanık modeline uygun olarak yanık oluşturuldu ve her iki grup eşit şartlarda 21 gün beslendi. Deney grubuna, $5 \mathrm{~mL} / \mathrm{kg} /$ gün L-glutamin + L-alanin içeren (Dipeptiven ${ }^{\circledR}$, Fresenius Kabi BadHamborg, Almanya) preparat oral yolla verildi. Yirmi bir günün sonunda tüm ratlar sakrifiye edildi. Tüm ratlardan steril şartlarda, karaciğer, ince bağırsak, yanık yarasından biyopsiler ve kan kültürleri alındı. Patolojik incelemede karaciğer ve ince bağırsak dokularındaki yapısal değişiklikler ve yara iyileşmesi değerlendirildi. Mikrobiyolojik incelemede ince bağırsak ve kan kültürleri kıyaslanarak L- glutamin + L-alaninin bakteriyel translokasyona etkisi araştırıldı.

Bulgular: Iki grup arasında ince bağırsak biyopsileri arasında hiçbir yapısal fark görülmedi. Karaciğer biyopsilerinde kontrol grubunda grade 1 hasarlanma mevcutken deney grubunda hasar tespit edilemedi. Yanık yarasından alınan deri biyopsilerinin patolojik incelemesinde deney grubunda epitelizasyon ve granulasyonun daha iyi olduğu tespit edildi. Mikrobiyolojik incelemede kontrol grubundaki iki ratın ince bağırsak ve kan kültürlerinde $S$. aureus, iki ratın ince bağırsak ve kan kültürlerinde de S.epidermidis olmak üzere toplamda dört ratta üreme tespit edildi.

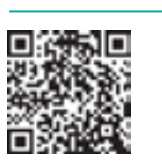

Address for Correspondence: Perçin Karakol, University of Health Sciences Turkey, Bağcılar Training and Research Hospital, Clinic of Plastic, Reconstructive and Aesthetic Surgery, İstanbul, Turkey

E-mail: ppercin@gmail.com ORCID: orcid.org/0000-0003-0068-2139 Received: 21.09.2020 Accepted: 15.12.2020

Cite this article as: Günay S, Karakol P, Bozkurt M, Durgun M. Bacterial Translocation Relationship with Enteral L-Glutamine and L-Alanine in Experimental Rat Burn Model. Bagcilar Med Bull 2021;6(1):79-87.

${ }^{\odot}$ Copyright 2021 by the Health Sciences University Turkey, Bagcilar Training and Research Hospital Bagcilar Medical Bulletin published by Galenos Publishing House. 


\section{Abstract}

replication of $S$. aures in the small intestine and blood culture and two rats showed replication of $S$. epidermidis in the small intestine and blood culture. No replication was determined in any rats from the experimental group.

Conclusion: In the light of findings acquired from this study done with experimental rat burn model, we think that the use of L-glutamine + $L$-alanine will have positive effects on wound healing and help preventing the bacterial translocation in burn patients as a supporting product.

Keywords: Bacterial translocation, burn, L-alanine, L-glutamine

\section{Öz}

Deney grubundaki hiçbir ratın ince bağırsak ve kan kültürlerinde üreme olmadı.

Sonuç: Deneysel rat yanık modelinde yapılan bu çalışmanın sonucunda elde ettiğimiz verilere göre, L-glutamin + L-alanin kullanımının, yanık hastalarının yara iyileşmesine olumlu etkisi olduğu, ek olarak da bakteriyel translokasyonu engellemeye yardımcı olduğu kanısına vardık.

Anahtar kelimeler: Bakteriyal translokasyon, L-alanin, L- glutamin, yanık

\section{Introduction}

Since severe burn cases with a large burn surface quickly enter the catabolic process, it is important to manage the process well starting from the early period. In addition to all the difficult stages such as fluid replacement, wound care, pain control, and replacement of electrolytes, enteral and parenteral nutritional supplement products are also needed (1).

Amino acids play an important role not only as protein building blocks but also as precursors in the biosynthesis of many important biological and physiological compounds. In severe stress situations such as sepsis, trauma, burns, malnutrition and prolonged oral nutrition and healing of surgical wounds, the need for glutamine exceeds its synthesis capacity and must be added to the diet. So, it becomes essential. The requirement of proteins, which are indispensable for life, is calculated according to the degree of the metabolic deficit, stress factor, and the degree of use and metabolization of the protein. Inflammation plays a vital role in the breakdown of the intestinal barrier, either directly or by inducing tumour necrosis factor-alpha. Studies in the literature reporting that glutamine increases intestinal barrier functions after both inflammation and immunosuppressive events are available (2).

Glutamine is vital as ammonia scavenger transport and as a precursor in nucleotide synthesis. It uses high amounts of glutamine in nucleotide synthesis to support the rapid conversion of the intestinal mucosa. In catabolic diseases supported by glutamine treatment, nitrogen balance and immune system function have been shown to improve and reduce mortality and morbidity (3). In addition to personal factors, it is important to protect the patient from infection during the burn healing process. In addition to systemic antibiotic treatment, the effect of food supplementation on the protection of bowel flora, mortality and morbidity reduction should not be ignored (4).
Many studies show that post-burn sepsis causes intestinal barrier disorder and damaged host defense. Bacterial translocation may increase the rate of infection in critically ill patients while leading to multiple organ failure. It was also found to be associated with enteral bacterial translocation in experimental studies that investigate morphological changes in rat intestinal villi after severe burns (5-7). Bacterial translocation (BT) occurs after thermal injury and may result from an ischemic intestine $(8,9)$. Some medications have been tried enterally and parenterally to reduce bacterial translocation, even the effects of hyperbaric oxygen and ozone are controversial today (10-13).

In this study, we aimed to determine the effect of L-alanine + L-glutamine preparation on post-burn sepsis, structural changes in the liver and small intestine, wound healing and on bacterial translocation.

\section{Materials and Methods}

After getting approval from the local institutional review board (Dicle University Local Ethics Committee no: 2012/42), 20 adult rats with an average weight of $330 \mathrm{~g}$ were used in this study. Each rat was caged singly and was provided rat food and water. All rats were first anesthetized with $90 \mathrm{mg} / \mathrm{kg}$ intraperitoneal (Ketalar ${ }^{\circledR}$, Pfizer). Then, the back of all rats was shaved. The shaved area was first wiped with povidone iodine, and then burned. According to the "rat burn model", a $170{ }^{\circ} \mathrm{C}$ stainless steel metal plate with equal elevation and equal pressure curve was burned for 30 seconds by touching the back skin of the rat. After burning, 20 rats were randomly divided into 2 groups and placed in separate cages. Throughout the entire experiment, all animals were housed in cages together so that 10 rats were in one cage under standard physical conditions. While both groups were fed in a standard way, additionally the preparation containing $5 \mathrm{~mL} / \mathrm{kg} /$ day L-glutamine + 
L- alanine (Dipeptiven ${ }^{\circledR}$, Fresenius Kabi BadHamborg, Germany) was given by oral gavage for 21 days for the experimental group. After 21 days, intra-cardiac blood was collected from all rats and they were sacrificed by decapitation. The blood was taken into the "Bactec pediatric ${ }^{\circledR}$ " blood culture tubes. Biopsies were taken from the liver, small intestine and wound of all rats after the sacrifice. While blood culture samples and biopsy samples taken from the small intestine were sent for microbiological examination, they were also examined pathologically.

\section{Histopathologic Analysis}

The tissue specimens were kept in $10 \%$ paraformaldehyde solution for 48 hours, followed by immersion into routine paraffin. Samples of 5-micron sections were taken from tissues embedded in paraffin blocks and were stained with Hematoxylin-Eosin. The sections obtained were evaluated by a specialist pathologist and classified with a light microscope (Table 1).

Classification of liver damage:

Grade 0: Minimal damage or none.

Grade 1: Mild injury characterized by cytoplasmic vacuoles and nuclear local pycnosis.

Grade 2: Moderate injury; no necrosis, ballooning in hepatocytes, cytoplasmic vacuolization, sinusoidal dilation, congestion, blurring of borders between cells.

Grade 3: Moderate to severe injury; coagulation necrosis, cytoplasmic hypereosinophilia, large sinusoidal dilation,

\section{Table 1. Histopathologic scoring}

\begin{tabular}{lll} 
Histopathologic score & \\
\hline \multirow{2}{*}{ Grade 0 } & Inflammation & No \\
& Vascularization & No \\
& Epithelization & No \\
& Granulation tissue & No \\
& Inflammation & Light \\
Grade 1 & Vascularization & Few capillaries \\
& Epithelization & Minimal epithelialization \\
& Granulation tissue & A thin layer \\
& Inflammation & Middle \\
Grade 2 & Vascularization & Well differentiated capillary system \\
& Epithelization & Totally, thin layer \\
& Granulation tissue & A thick layer \\
& Inflammation & Severe \\
Grade 3 & Vascularization & Extensive neovascularization \\
& Epithelization & Totally, thick layer \\
& Granulation tissue & A uniform thick layer
\end{tabular}

and congestion areas.

Grade 4: Serious injury; disruption of the architectural structure of cells with coagulation necrosis and distribution, bleeding into hepatic chords.

Classification of small bowel damage:

Grade 0: No damage.

Grade 1: Edema, congestion, mild inflammation.

Grade 2: Mild inflammation, mild hemorrhage.

Grade 3: Was scored as severe inflammation, intense bleeding areas and necrosis.

\section{Microbiological Analysis}

In our study, small intestine tissue samples from group 1 (control group) and group 2 (experimental group) subjects were taken for microbiological examination within 10 minutes in a sterile container. For this, tissue samples were planted on 2 sheep blood agar, 1 mac conkey agar, and 1 chocolate agar. Samples were incubated at $36.8^{\circ} \mathrm{C}$ for 24 hours, and microorganisms that reproduced at the end of the incubation period were identified through conventional methods and automatization [Phoenix ${ }^{\mathrm{TM}} 100$ (Becton Dickinson, MD, USA)].

The other sheep blood agar media was incubated at 36.8 ${ }^{\circ} \mathrm{C}$ for 48 hours in anaerobic medium (in the GASPAK jar). Conventional methods and VITEK 2 (bioMérieux, France) fully automated identification system were used for the typing of anaerobic microorganisms. On the other hand, blood samples taken from group 1 and group 2 subjects were inoculated into the BACTEC peds plus/F (BD, Sparks, MD) ${ }^{\circledR}$ blood culture bottles. Blood samples $(1 \mathrm{~mL})$ from reproductive blood culture bottles were planted in sheep blood agar, mac conkey agar, and chocolate agar media.

Samples were incubated for 24 hours at $36.8{ }^{\circ} \mathrm{C}$ and microorganisms grown at the end of the incubation period were identified by conventional methods and automated system [Phoenix TM 100 (Becton Dickinson, USA)].

The microorganism species growing in the intestinal tissue and blood culture bottles of subjects in group 1 and group 2 were recorded. If the microorganism breeding in the small intestine culture of the same rat also reproduced in the blood culture, it was interpreted that microorganism was the cause and that rat entered the sepsis. The reproduction of different microorganisms in the same rat was evaluated as contamination. 


\section{Statistical Analysis}

As statistical tests; in evaluating continuous measurement variables, the Mann-Whitney U test, or the Student's t-test, was used according to their unequal or equal distribution. The categorical variables were evaluated with the chi-square test or the chi-square Fisher test. The results obtained were considered statistically significant when $\mathrm{p}<0.05$.

\section{Results}

Pathological scoring was achieved as a result of the evaluation of tissue specimens; the histopathological results in the study are provided (Table 2, 3).

In histopathological examination, no difference was observed between the two groups in the small intestine structures (Figure 1,2). In the examination of the liver tissues, eight of ten rats in the control group had grade 1 damage, whereas no rat in the experimental group was damaged (Figure 3,4 ). When comparing the control group with the experimental group in the examination of the burn areas, epithelialization, granulation, and inflammation were less in the experimental group, and vascularization was similar in both groups.

Microbiological analysis results are given for group 1 (Table 4) and group 2 below (Table 5).

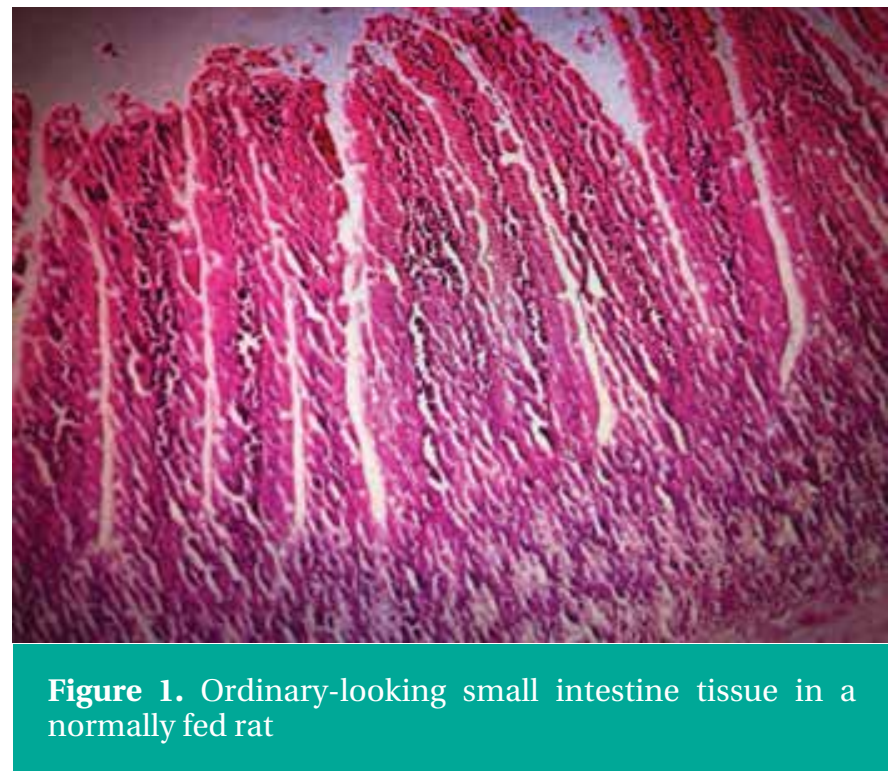
Table 2. Histopathological examination results in the control group

\begin{tabular}{|c|c|c|c|c|c|}
\hline Group & Liver damage & Skin inflammation & Skin granulation & Skin vascularization & Skin epithelization \\
\hline GRP.1.1 & 1 & 3 & 1 & 2 & 0 \\
\hline GRP.1.2 & 1 & 3 & 2 & 1 & 0 \\
\hline GRP.1.4 & 0 & 2 & 0 & 2 & 0 \\
\hline GRP.1.5 & 1 & 3 & 1 & 3 & 0 \\
\hline GRP.1.8 & 1 & 3 & 2 & 2 & 0 \\
\hline GRP.1.9 & 1 & 3 & 2 & 1 & 0 \\
\hline GRP.1.10 & 1 & 2 & 2 & 1 & 0 \\
\hline
\end{tabular}

Table 3. Histopathological examination results in the experimental group

\begin{tabular}{llllll} 
Group & Liver damage & Skin inflammation & Skin granulation & Skin vascularization & Skin epithelization \\
\hline GRP. 2.1 & 0 & 1 & 2 & 2 & 1 \\
GRP. 2.2 & 0 & 2 & 2 & 2 & 2 \\
GRP. 2.3 & 0 & 1 & 3 & 3 & 2 \\
GRP. 2.4 & 0 & 1 & 2 & 2 & 1 \\
GRP. 2.5 & 0 & 1 & 3 & 1 & 2 \\
GRP.2.6 & 0 & 2 & 2 & 1 & 1 \\
GRP.2.7 & 0 & 1 & 2 & 1 & 2 \\
GRP.2.8 & 0 & 1 & 2 & 2 & 1 \\
GRP.2.9 & 0 & 1 & 3 & 3 & 2 \\
GRP.2.10 & 0 & 2 & 3 & & 1 \\
\hline
\end{tabular}


In microbiological examination, active microorganism was detected in 4 rats in the small intestine and blood cultures in the control group, whereas no active microorganism was observed in the experimental group. The probability of positivity in the small intestine culture between the two groups was significantly higher in the control group.

In statistical analysis, inflammation in liver tissue was significantly less in the experimental group $(\mathrm{p}=0.001)$. In the experimental group, epithelization and granulation in burn tissue were significantly higher and inflammation was significantly less than in the control group $(\mathrm{p}<0.05)$ (Figure 5). There was no significant difference in vascularization $(\mathrm{p}=0.88)$

\section{Discussion}

Burn injuries are an important public health problem. Although it is seen in every age group, it is more common

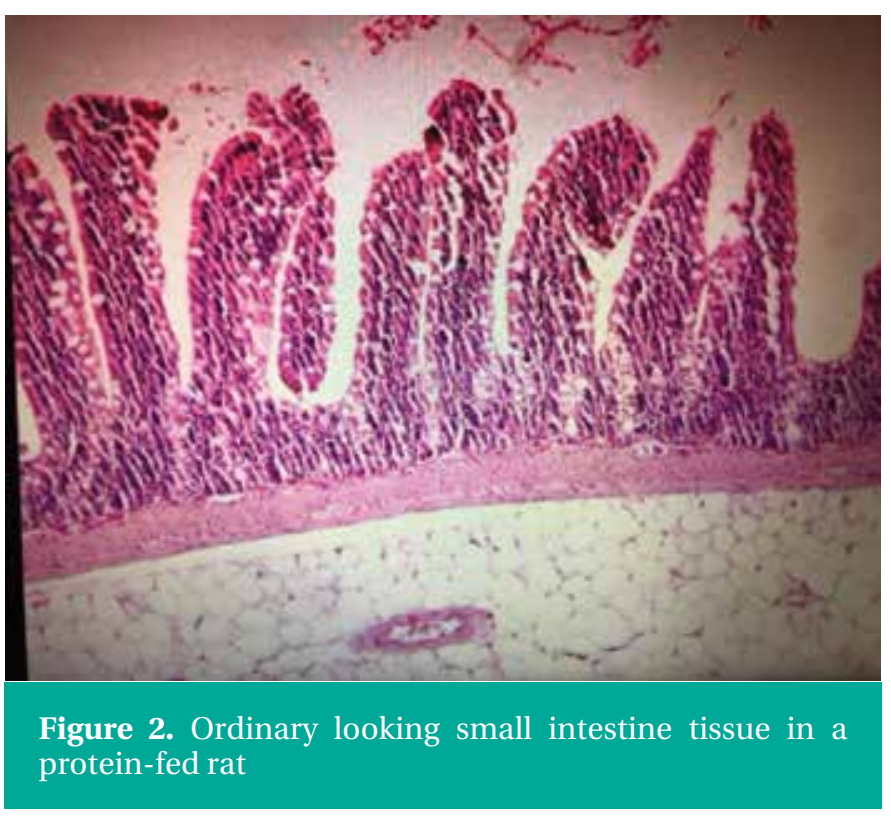

\begin{tabular}{llll}
$\begin{array}{l}\text { Table } \\
\text { Rat } \\
\text { number }\end{array}$ & $\begin{array}{l}\text { Positive culture } \\
\text { in the small } \\
\text { intestine }\end{array}$ & $\begin{array}{l}\text { Positive culture } \\
\text { in the blood }\end{array}$ & Evaluation \\
\hline $\mathbf{1}$ & S. aureus & S. aureus & Active \\
$\mathbf{2}$ & S. epidermidis & S. epidermidis & Active \\
$\mathbf{3}$ & E. coli & Negative culture & Contamination \\
$\mathbf{4}$ & S. aureus & S. aureus & Active \\
$\mathbf{5}$ & S. epidermidis & S. epidermidis & Active \\
$\mathbf{6}$ & Negative culture & Negative culture & - \\
$\mathbf{7}$ & Negative culture & Negative culture & - \\
$\mathbf{8}$ & Negative culture & Negative culture & - \\
$\mathbf{9}$ & Negative culture & Negative culture & - \\
$\mathbf{1 0}$ & Negative culture & Negative culture & - \\
\hline
\end{tabular}

in children and the elderly compared to the community average. $90 \%$ of burn injuries are mild enough to be tracked from home. While wide and deep burns are treated in hospital, there may be other complications related to longterm hospitalization. Inpatient hospitalization increases the susceptibility to hospital infections in addition to socioeconomic and psychological problems. Gudaviciene,

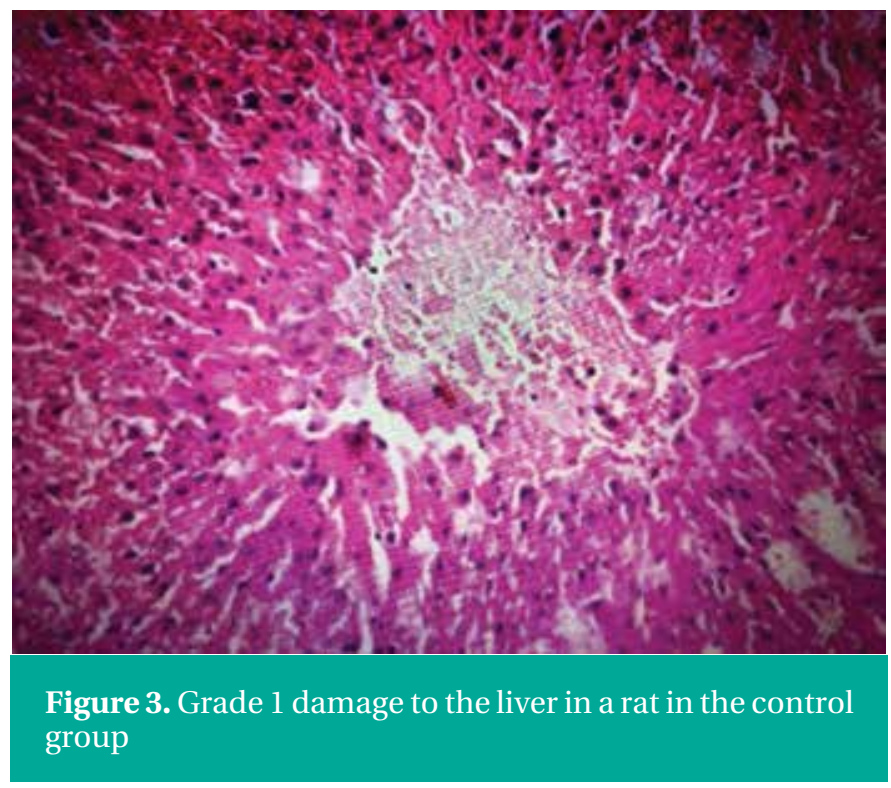

Table 5. Microbiological evaluation of the experimental group

\begin{tabular}{|c|c|c|c|}
\hline $\begin{array}{l}\text { Rat } \\
\text { number }\end{array}$ & $\begin{array}{l}\text { Positive culture in the } \\
\text { small intestine }\end{array}$ & $\begin{array}{l}\text { Positive } \\
\text { culture } \\
\text { in the } \\
\text { blood }\end{array}$ & Evaluation \\
\hline 1 & Negative culture & $\begin{array}{l}\text { Negative } \\
\text { culture }\end{array}$ & - \\
\hline 2 & $\begin{array}{l}\text { Peptostreptococcus spp., } \\
\text { E. coli, alpha hemolytic } \\
\text { streptococcus }\end{array}$ & $\begin{array}{l}\text { Negative } \\
\text { culture }\end{array}$ & Contamination? \\
\hline 3 & Negative culture & $\begin{array}{l}\text { Negative } \\
\text { culture }\end{array}$ & - \\
\hline 4 & Negative culture & $\begin{array}{l}\text { Negative } \\
\text { culture }\end{array}$ & - \\
\hline 5 & Negative culture & $\begin{array}{l}\text { Negative } \\
\text { culture }\end{array}$ & - \\
\hline 6 & Negative culture & $\begin{array}{l}\text { Negative } \\
\text { culture }\end{array}$ & - \\
\hline 7 & Negative culture & $\begin{array}{l}\text { Negative } \\
\text { culture }\end{array}$ & - \\
\hline 8 & Negative culture & $\begin{array}{l}\text { Negative } \\
\text { culture }\end{array}$ & - \\
\hline 9 & Negative culture & $\begin{array}{l}\text { Negative } \\
\text { culture }\end{array}$ & - \\
\hline 10 & Negative culture & $\begin{array}{l}\text { Negative } \\
\text { culture }\end{array}$ & - \\
\hline
\end{tabular}


in his study, has reported that burn trauma accounts for $5-12 \%$ of all traumas, $10 \%$ of all burns are hospitalized, the rate of mortality increases rapidly as the burn rate exceeds

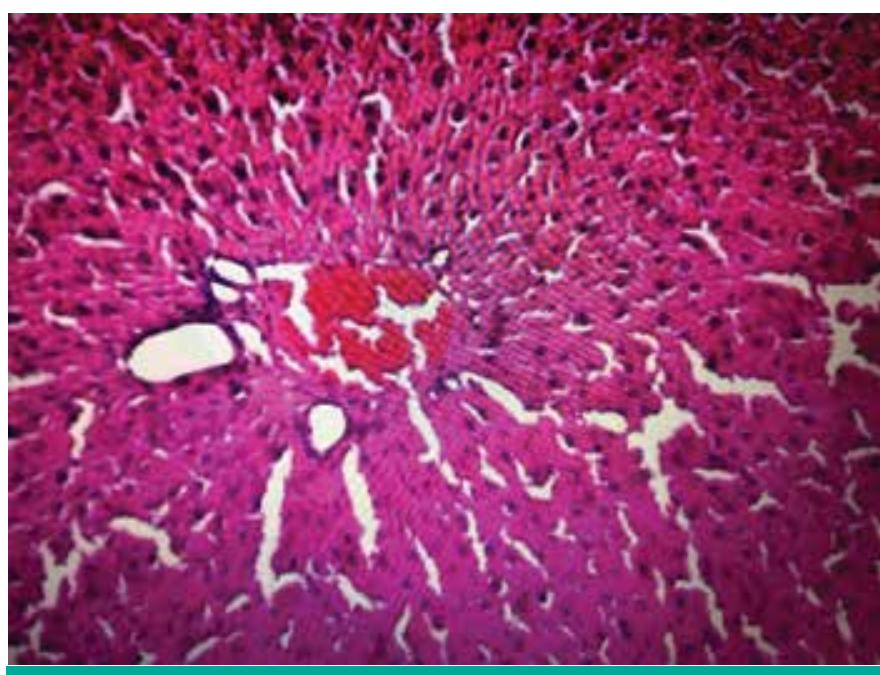

Figure 4. The usual-looking liver tissue in a rat in the experimental group

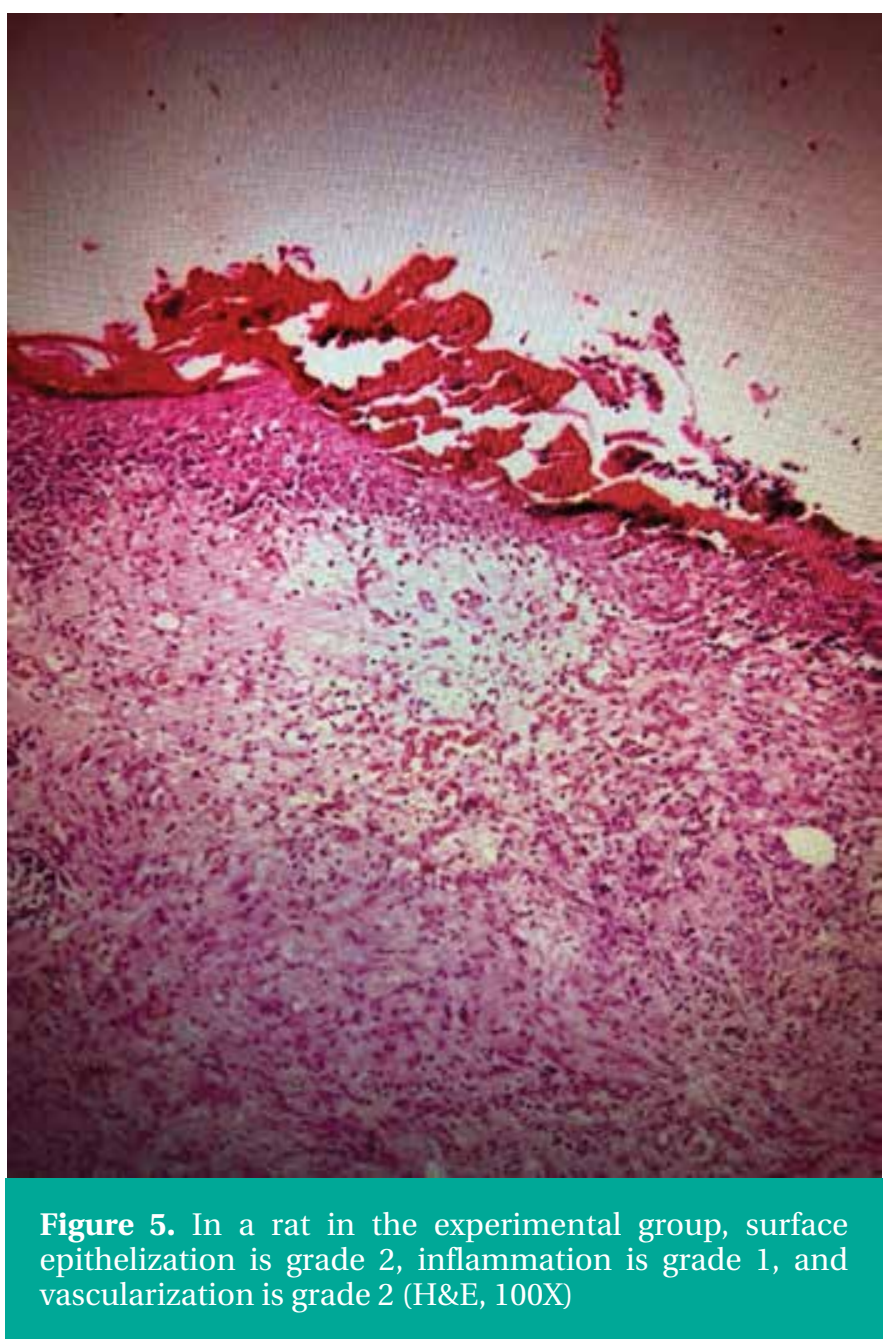

$20 \%$, and the most common causes of death are lung edema, pneumonia, sepsis and multiple organ failure. They reported that nutritional support contributed significantly to possible complications and survival and shortened the length of hospital stay (14). Severe burn damage causes serious metabolic disorders and increased metabolic rate. As a result, protein energy malnutrition occurs. This situation delays wound healing, increases muscle loss, causes growth and development retardation in children, and increases the tendency to infections over time. In the study of Grau Carmona et al. (15), it was reported that the hypermetabolic response resulting from thermal injuries is very severe and basal metabolism can increase up to 2 times. It was stated that these patients would need intensive nutritional support and that nutritional supplement should not be in the form of caloric supplement only. In particular, arginine + glutamine infusion, vitamin $\mathrm{C}$, vitamin A and zinc administration have been reported to reduce morbidity and mortality in patients, as well as accelerating wound healing (15). Therefore, nutritional support is vital in preventing complications in the treatment process in large burn injuries. In the early 1970s, with the inclusion of nutritional support in burn treatment, the survival rates of people exposed to this trauma have been shown to increase significantly (16). Since then, research on the subject has continued increasingly in a wide variety of branches of nutrition. Nutritional products to be given to critical patients have been developed rapidly in recent years and new products have been released. What is given to which patient, which way to give and the full effect of the given substance are the main subjects of the research. In a study conducted on 30 patients in the burn intensive care unit, Guo et al. (2) concluded that cellular immune function increased in 14 patients in the group fed with an Arginine enriched enteral nutrition product. In the study of resuscitated severe burns by Yan et al. (3), early recovery was observed after resuscitation in the group fed with food supplemented with L-arginin. Peng and Weng (4) have reported in their studies that, in both patients and animal experiments, glutamine reduces intestinal damage, strengthens immunity and shortens hospital stay of burn patients. Previous studies have shown that post-burn injury is associated with impaired integrity of the intestinal barrier, increased intestinal permeability, more serious infections, and advanced septic complications $(5,6)$.

The metabolic rate varies between $118 \%$ and $210 \%$ in the estimation made according to the Harris-Benedict equation in adult patients who have experienced burn injury covering $25 \%$ of the body surface area (17). In burn 
patients, whose more than $40 \%$ of the body surface area is affected, the metabolic rate at rest at $33{ }^{\circ} \mathrm{C}$ is $180 \%$ of the basal metabolic rate in acute application, $150 \%$ when the wounds are fully closed, $140 \% 6$ months after the injury, 9 it reaches $120 \%$ after a month and $110 \%$ after 1 year. If such high calorie loss is not met, the patient develops weight loss and increases mortality and morbidity.

There are many studies on how to use supplements. In a study by De Luis et al. (18), parenteral nutrition was reported to be more beneficial than enteral nutrition, especially in a number of diseases such as burns, pancreatitis and septic inflammatory bowel disease (18). In the study of Soeters and Grecu (19), glutamine supplements were recommended to severe burn patients and the parenteral route was reported to be more beneficial than the enteral route. In the study conducted by Burns and Gill (20), it was reported that in an adult patient with short bowel syndrome, who had to be fed parenterally, parenteral nutrition caused complications such as liver lubrication, stenosis in the hepatic pathways, and existing complications in the liver, including omegaven, regressed (20). Although oral feeding is recommended in patients who can take orally in accordance with all these studies, there are studies reporting that parenteral delivery of additive proteins such as L-alanine and L-glutamine will be more beneficial. Both the enteral form and the parenteral form of L-alanine and L-glutamine have been developed commercially. Supplemental nutrients given in patients with deep burns can reduce mortality and morbidity. Although there are many studies on the content of supplementary nutrients, these studies are generally concentrated on fish oil (m-3), L-glutamine, and L-alanine. L-alanine turns into a nonessential amino acid arginine in the body. Arginine is a stimulant in growth hormone, prolactin, glucagon and insulin release, as well as a nitric oxide (NO) precursor. NO has been reported to regulate vasodilator and hepatic protein synthesis and reduce anti-inflammatory mediator release, creating an anti-inflammatory effect and suppressing the harmful inflammatory response. Arginine plays a major role in wound healing as it plays a key role in collagen synthesis. In recent studies, supplementation of post-traumatic arginine has been shown to reduce intestinal damage and accelerate wound healing. There is no consensus on its effect on bacterial translocation. There are studies reporting that it is effective in this regard, as well as studies that say it is not effective.

Glutamine is abundant in plasma and skeletal muscles and is classified as a non-essential amino acid. However, there are studies reporting that plasma levels decrease significantly after traumas, especially burns or severe surgical operations, so it may be essential in some cases. One of the most important tasks of glutamine is the fuel for fast-regenerating cells, especially erythrocytes. Many studies have been conducted on its effect on the gastrointestinal tract and its regulatory effect on intestinal functions has been demonstrated. Glutamine is recommended as an additional nutrient to prevent bacterial translocation in patients receiving radiotherapy or chemotherapy, fed parenterally for a long time, and in septic patients with small bowel damage expected. It has been demonstrated in clinical studies that multiple organ failure due to sepsis decreases in patients who are given glutamine as an additional nutrient (21). Glutamine is the leading molecule of glutathione, an antioxidant. Glutathione is used in visceral protein synthesis in the liver and ammonia synthesis in the kidney. Glutathione, which is abundant in muscle tissue, can also be obtained from the Krebs cycle in cases of increased stress. However, this situation causes muscle loss in the patient. In the study of Donmez et al. (22), in the sepsis model created in rats, the effect of glutamine and growth hormone on opening the anastomosis was evaluated after fistula repair in the intestines (22). In the same study, the combination of glutamine and growth hormone has been reported to have positive effects on wound healing in the intestinal wall and the use of glutamine in patients who have undergone intrabdominal surgery has been proposed.

In the study of Quirino et al. (23), the effect of arginine on bacterial translocation was investigated. In the intestinal obstruction model of the rats, the control group was fed in the standard way, while the experiment group was given food rich in arginine for 7 days. At the end of the $7^{\text {th }}$ day, E. coli marked with Tc-99m was given from the small intestine lumen, and after 24 hours, all rats were sacrificed and the levels of marked bacteria in blood, mesentery, spleen, lung and liver were measured. In the control group, a statistically significant bacterial translocation was detected in the experimental group. In the same study, it was emphasized that arginine was effective in preventing bacterial translocation and it was suggested to be used in patients expected to have bacterial translocation.

Lack of specific modeling for bacterial translocation detection is among the limitation criteria. In addition, other limitations of the study included that the burn caused tissue defect susceptible to additional infections and the samples obtained were difficult to protect from 
contamination. In order to prevent this, the defect areas of rats were covered with wound dressing spray for a day. And while tissue samples were taken, they were studied quickly and easily fixed.

Unlike other studies, in our study, no difference was found in the pathological examination of small intestine samples between the rats in the control group and the rats in the experimental group. On the other hand, in the small intestine and blood cultures taken in 2 rats in the control group, $S$. aureus was reproduced. However, in the other 2 rats, $S$. epidermidis was reproduced. These positive results were statistically significant and were interpreted as bacterial translocation. For this reason, although we did not find the positive effect of glutamine and alanine on the intestinal wall in our study, we think that it has positive effects in preventing bacterial translocation.

\section{Conclusion}

In this study, while no positive culture occurred in the experimental group in blood culture examination, positivity was detected in 4 rats in the control group. Accordingly, it suggests that giving L-alanine L-glutamine as oral nutritional supplement has protective effects against sepsis. In the histopathological examination of liver biopsies, no damage was detected in the experimental group, while grade 1 damage was observed in the control group, suggesting that oral L-alanine L-glutamine administration may have a protective effect in severe burns cases. While inflammation was moderate in skin biopsies taken from the control group, inflammation was less in skin biopsies taken from the experimental group. While the development of granulation tissue was low and irregular in the control group, it was found to be more regular and higher in the experimental group. While epithelialization was not observed in the control group, it was moderate in the experimental group. Our study has showed that oral L-alanine L-glutamine administration as a supplement has a positive effect on burn wound healing. We believe that this application will also contribute to preventing complications that may develop in severe burns and a secondary reduction in mortality and morbidity.

\section{Ethics}

Ethics Committee Approval: After getting approval from the local institutional review board (Dicle University Local Ethics Committee no: 2012/42).

Informed Consent: Consent was not obtained because it was an animal study.
Peer-review: Externally and internally peer-reviewed.

\section{Authorship Contributions}

Concept: M.B., M.D., S.G., P.K., Design: P.K., S.G., M.D., Data Collection or Processing: P.K., S.G., M.D., Analysis or Interpretation: S.G., P.K., M.D., M.B., Literature Search: P.K., S.G., Writing: P.K., S.G., M.B.

Conflict of Interest: No conflict of interest was declared by the authors.

Financial Disclosure: The authors declared that this study received no financial support.

\section{References}

1. Montejo JC, Zarazaga A, Lopez-Martinez J, Blesa AL, Celaya S, Conejero R, et al. Immunonutrition in critically ill patients. JPEN J Parenter Enteral Nutr 2004;28(3):192-193.

2. Guo GH, Xu C, Bai XJ, Zhan JH, Zhang HY, Zhang ZA, et al. Effects of arginine enriched enteral nutrition on nutritional status and cellular immunity in burn patients. Zhonghua Shao Shang Za Zhi 2009;25(3):211-214

3. Yan H, Peng X, Huang Y, Zhao M, Li F, Wang P. Effects of early enteral arginine supplementation on resuscitation of severe burn patients. Burns 2007;33(2):179-184.

4. Peng X, Wang SL. Glutamine and immunonutrition for burn patients. Zhonghua Shao Shang Za Zhi 2009;25(5):321-324.

5. Sengezer M, Selmanpakoğlu N, Duman H, Çetin C. Epidemiological analysis of burn injuries in Gülhane Military Medical Academy Burn Center. Türk Plast Cer Derg 1995;3(2):74-77.

6. Pruit BA, Mason AD. Epidemiological demographic and outcome characteristics of burn injury. In Total burn care, Herndon DN (editor). London: W.B. Saunders, 1996:5-15.

7. Rong XZ, Zhang T, Yang RH, Huang XH, Li QH. Morphological changes in intestinal villi after severe burns in rats. Zhonghua Shao Shang Za Zhi 2005;21(6):459-461.

8. Chen DC, Ma LQ, Liu SZ. Effects of rhubarb on intestinal flora and bacterial translocation in rats with sepsis. Zhongguo Wei Zhong Bing Ji Jiu Yi Xue 2009;21(1):17-20.

9. Wen ZL, Zhang LD, Liu SZ, Liu J, Chen YZ, Chen DC. Effect of broad-spectrum antibiotics on bacterial translocation in burned or septic rats. Chin Med J (Engl) 2019;132(10):1179-1187.

10. Akin ML, Gulluoglu BM, Erenoglu C, Dundar K, Terzi K, Erdemoglu A, et al. Hyperbaric Oxygen Prevents Bacterial Translocation in Thermally Injured Rats. J Invest Surg 2002;15(6):303-310.

11. Himuro H. The Effect of Ozone on Colonic Epithelial Cells. Kurume Med J 2018;64(4):75-81.

12. Jiang J, Ren Z, Chen L, Jiang L, Xie HY, Zhou L, et al. Enteral supplementation with glycyl-glutamine improves intestinal barrier function after liver transplantation in rats. Hepatobiliary Pancreat Dis Int 2011;10(4):380-385.

13. Kesici S, Türkmen A, Kesici U, Altan A, Polat E. Effects of enteral and/or parenteral glutamine on intestinal mucosa and on intestinal levels of blood glutamine, TNF-, IL-10 in the experimental sepsis model. Intensive Care Med 2010;36(Suppl 2):372. 
14. Gudaviciene D, Rimdeika R, Adamonis K. Nutrition of burned patients. Medicina (Kaunas) 2004;40(1):1-8.

15. Grau Carmona T, Rincón Ferrari MD, García Labajo D. [Nutritional support in burnt patients]. Nutr Hosp 2005;20(Suppl 2):44-46.

16. Kagan RJ. Metabolism and nutrition in the burned patient. Nutr Clin Pract 1991;6(1):1-2.

17. Dickerson RN, Gervasio JM, Riley ML, Murrell JE, Hickerson WL, Kudsk KA, et al. Accuracy of predictive methods to estimate resting energy expenditure of thermally-injured patients. JPEN J Parenter Enteral Nutr 2002;26(1):17-29.

18. De Luis D, Aller R, Culebras J. Recommendations for artificial nutritional support in critically ill patients. Med Clin (Barc) 2006;127(6):232-236.

19. Soeters PB, Grecu I. Have we enough glutamine and how does it work? A clinician's view. Ann Nutr Metab 2012;60(1):17-26.
20. Burns DL, Gill BM. Reversal of parenteral nutrition-associated liver disease with a fish oil-based lipid emulsion (Omegaven) in an adult dependent on home parenteral nutrition. JPEN J Parenter Enteral Nutr 2013;37(2):274-280.

21. Piattoly T, Welsch M. "L-Glutamine Supplementation: Effects on Recovery from Exercise." Medicine and Science in Sports and Exercise 36 (2004): n. pag.

22. Donmez R, Oren D, Ozturk G, Kisaoglu A, Ozogul B, Atamanalp SS. The combined effects of glutamine and growth hormone on intestinal anastomosis in the rat intra-abdominal sepsis model. J Surg Res 2013;182(1):142-145.

23. Quirino IE, Correia MI, Cardoso VN. The impact of arginine on bacterial translocation in an intestinal obstruction model in rats. Clin Nutr 2007;26(3):335-340. 